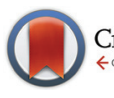

CrossMark \& click for updates

Cite this: Polym. Chem., 2015, 6 , 7447

Received 23rd July 2015, Accepted 29th August 2015

DOI: $10.1039 / c 5 p y 01156 f$

www.rsc.org/polymers

\section{Controlling the synthesis of degradable vinyl polymers by xanthate-mediated polymerization $\uparrow$}

\author{
Craig A. Bell, a,b,c Guillaume G. Hedir, ${ }^{a}$ Rachel K. O'Reilly*a and Andrew P. Dove*a
}

\section{Introduction}

Degradable polymers obtained by radical ring-opening polymerization (rROP) of cyclic ketene acetals (CKAs) have recently attracted significant interest as they represent a facile alternative to conventional ring-opening polymerization for the synthesis of aliphatic polyesters. ${ }^{1-3}$ The 5-, 6- and 7-membered CKAs formed from the appropriate aliphatic diols, as well as the methyl- and phenyl- substituted versions have been used to afford a range of polyester materials. ${ }^{4-6}$ The 7 -membered CKA, 2-methylene-1,3-dioxepane (MDO), has been the most widely studied as a consequence of the polymer's repeat unit being identical to poly( $\varepsilon$-caprolactone) (PCL) ${ }^{7,8}$ a degradable polyester that is widely studied and applied in the biomedical field. ${ }^{9-11}$ Conventional methodologies to synthesize PCL typically use anionic or metal-catalyzed ROP of $\varepsilon$-caprolactone and require rigorous synthetic procedures in order to produce polymers of high purity. ${ }^{12,13}$ In contrast, poly(MDO) can be synthesized by conventional radical polymerization techniques and is therefore more easily accessible, requiring less stringent synthetic conditions.

\footnotetext{
${ }^{a}$ Department of Chemistry, University of Warwick, Gibbet Hill Road, Coventry, CV4 7AL, UK. E-mail: r.k.o-reilly@warwick.ac.uk,a.p.dove@warwick.ac.uk ${ }^{b}$ Australian Institute for Bioengineering and Nanotechnology, The University of Queensland, St Lucia, Queensland 4072, Australia ${ }^{c}$ Centre for Advanced Imaging, The University of Queensland, St Lucia, Queensland 4072, Australia

$\dagger$ Electronic supplementary information (ESI) available: Characterization of all CTAs, homopolymers and copolymers. See DOI: 10.1039/c5py01156f
}

The mechanism for rROP involves the formation of a primary radical through electronic rearrangement and $\beta$-scission. As such, copolymers of MDO have been synthesized using a vast array of radically-polymerizable vinyl monomers. These include hydrophobic monomers such as ethylene, ${ }^{14}$ styrene (Sty) ${ }^{14-19}$ acrylonitrile (AN) ${ }^{19,20}$ vinyl acetate (VAc) ${ }^{21-23}$ and methyl methacrylate (MMA) ${ }^{20,24,25}$ as well as hydrophilic monomers such as poly(ethylene glycol) methyl ether methacrylate (PEGMA), ${ }^{26,27} N, N$-dimethylaminoethyl methacrylate (DMAEMA), ${ }^{28-30} \mathrm{~N}$-isopropylacrylamide (NIPAM), ${ }^{31,32}$ and $N$-vinylpyrrolidone (NVP). ${ }^{33,34}$ However, with the exception of less activated monomers (LAMs) such as VAc, the reactivity ratios for these copolymerizations indicate that final polymer compositions are more gradient-like or blocky, not statistical. ${ }^{17,25,29,35}$

Control of polymerizations incorporating CKAs has also been attempted through reversible-deactivation radical polymerization (RDRP) techniques such as Nitroxide-Mediated Polymerization (NMP), ${ }^{19,36}$ Atom Transfer Radical Polymerization (ATRP), ${ }^{37-39}$ and Reversible Addition-Fragmentation Chain-Transfer Polymerization/Macromolecular Design by Interchange of Xanthates (RAFT/MADIX) ${ }^{40}$ but there are only a handful of examples where these techniques have been used to control copolymerizations with MDO. Using BlocBuilder MA alkoxyamine initiator (SG1) to mediate the copolymerization of PEGMA or MMA, AN, and MDO, Delplace et al. have demonstrated control with final dispersities, $D_{\mathrm{M}},<1.4$. However, the molar feeds used were only 20 or $40 \mathrm{~mol} \%$, and all MDO incorporations into the final polymers were determined qualitatively from hydrolytic degradation. ${ }^{19,20}$ We have also recently shown control over VAc/MDO copolymerizations. Using xanthates to 
mediate the polymerization, initial MDO monomer feeds of 30 and $70 \mathrm{~mol} \%$ yielded polymers with predictable molecular weights and final dispersities, $\bigoplus_{\mathrm{M}},<1.6$. Additionally, these polymers were shown to have retained chain-end functionality through chain growth of VAc. ${ }^{22}$

Homopolymerization of MDO has predominantly been performed by free radical polymerization (FRP) and there are only a handful of studies that have attempted to synthesize poly (MDO) using RDRP techniques. ${ }^{41,42}$ The use of NMP enabled the controlled synthesis of polymers with greater degrees of control than conventional FRP. However, these studies enlisted the use of TEMPO as the mediating nitroxide, thus requiring high reaction temperatures and long polymerization times to obtain $M_{\mathrm{n}} \leq 8.5 \mathrm{kDa}$ while maintaining some control over the polymerization $\left(\oslash_{M}<2\right)$.

Herein, we report the optimization of CTA structure for the RAFT/MADIX synthesis of VAc/MDO copolymers. Further study of the polymerization process revealed that loss of control in the polymerization was a result of loss of the xanthate functionality through a Z-group fragmentation mechanism that leads to the formation of carbonodithioate functionality, confirmed by ${ }^{13} \mathrm{C}$ nuclear magnetic resonance (NMR) spectroscopy. Using a $p$-methoxyphenyl xanthate CTA, greater control over the polymerization was demonstrated with reduced dispersities than have previously been reported and greater chain-end retention. We also report on the first example of homopolymerization of MDO using xanthates. Despite the low conversions, the presence of the CTA also produced poly(MDO) with high end-group retention, as confirmed by ${ }^{1} \mathrm{H}$ NMR and MALDI-ToF MS analysis, and post-polymerization functionalization through aminolysis and Michael addition of propargyl methacrylate to form alkyne functional poly(MDO).

\section{Experimental}

\section{Materials and methods}

The following chemicals were used as received; alumina, activated basic $\left(\mathrm{Al}_{2} \mathrm{O}_{3}\right.$ : Sigma-Aldrich, Brockmann I, standard grade, 150 mesh, $58 \AA$ ), carbon disulfide $\left(\mathrm{CS}_{2}\right.$ : Fisher Scientific, AR grade), hexylamine (Sigma-Aldrich, 99\%), magnesium sulfate $\left(\mathrm{MgSO}_{4}\right.$ : anhydrous, Fisher Scientific, LR grade), methyl 2-bromopropionate (MBP: Sigma-Aldrich, 98\%), methyl bromoacetate (MBA: Sigma-Aldrich, 97\%), $N$-methylmaleimide (Sigma-Aldrich, 97\%), silica gel ( $\mathrm{SiO}_{2}$ : Apollo Scientific, 40-63 $\mu \mathrm{m}$ ), sodium chloride ( $\mathrm{NaCl}$ : Fisher Scientific, >99\%), sodium hydride (NaH: Sigma-Aldrich, $60 \mathrm{wt} \%$ dispersion in mineral oil), sodium hydrogen carbonate $\left(\mathrm{NaHCO}_{3}\right.$ : Fisher Scientific, $>99 \%)$, triethylamine $\left(\mathrm{Et}_{3} \mathrm{~N}\right.$ : Fisher Scientific, $>99 \%$ ). The following solvents were used as received; acetone (VWR International, AR grade), chloroform $\left(\mathrm{CHCl}_{3}\right.$ : VWR International, AR grade), d-chloroform ( $\mathrm{CDCl}_{3}$ : Apollo, $\left.>99 \%\right), \mathrm{d}_{6}$ benzene $\left(\mathrm{C}_{6} \mathrm{D}_{6}\right.$, Apollo, $\left.>99.5 \%\right)$, dichloromethane $\left(\mathrm{CH}_{2} \mathrm{Cl}_{2}\right.$ : VWR International, AR grade), diethyl ether (Fisher Scientific, LR grade), N,N-dimethylformamide (DMF: Sigma-Aldrich,
HPLC grade), ethyl acetate (EtOAc: Fisher Scientific, LR grade), 1-hexanol (Acros Organics, 98\%), petroleum spirit (BR 40-60 ${ }^{\circ} \mathrm{C}$, VWR International, AR grade), and 2-propanol (IPA, VWR International, AR grade). Tetrahydrofuran (THF: VWR International, AR grade) was dried using solvent towers. 2,2'azobis(2-methylpropionitrile) (AIBN: Molekula) and 1,1'-azobis(cyclohexanecarbonitrile) (ABCN: Sigma-Aldrich, 98\%) were recrystallized from acetone prior to use. Vinyl acetate (VAc: Sigma-Aldrich, $\geq 99 \%$ ) was dried and vacuum distilled over $\mathrm{CaH}_{2}$ to remove the inhibitor and residual water. 2-Methylene1,3-dioxepane (MDO) was synthesized using the previously described method of Bailey et al. ${ }^{1}$ then dried and vacuum distilled over $\mathrm{CaH}_{2}$. Both monomers were degassed by freezepump-thaw and transferred into a glove-box ready for use. Propargyl methacrylate (Alfa Aesar, 98\%) was used as received.

$O$-ethyl-S-ethyl 2-propionylxanthate (CTA 3) was synthesized using the previously described method of Skey et al. ${ }^{43}$

\section{General considerations}

Nuclear Magnetic Resonance spectrawere recorded at $400 \mathrm{MHz}\left({ }^{1} \mathrm{H}\right.$ $\mathrm{NMR}$ ) and $100 \mathrm{MHz}\left({ }^{13} \mathrm{C} \mathrm{NMR}\right)$ in $\mathrm{CDCl}_{3}$ on a Bruker DPX-400 spectrometer at $293 \mathrm{~K}$. Chemical shifts are reported as $\delta$ in parts per million (ppm) and referenced to the chemical shift of the residual solvent resonances $\left(\mathrm{CDCl}_{3}{ }^{1} \mathrm{H}: \delta=7.26 \mathrm{ppm} ;{ }^{13} \mathrm{C}: \delta=\right.$ $77.16 \mathrm{ppm})$. The resonance multiplicities are described as $\mathrm{s}$ (singlet), d (doublet), t (triplet), q (quartet) or m (multiplet).

Size exclusion chromatography (SEC) analyses were performed on a system composed of a Varian 390-LC-Multi detector using a Varian Polymer Laboratories guard column (PLGel $5 \mu \mathrm{M}, 50 \times 7.5 \mathrm{~mm}$ ), two mixed D Varian Polymer Laboratories columns (PLGel $5 \mu \mathrm{M}, 300 \times 7.5 \mathrm{~mm}$ ) and a PLAST RT autosampler. Detection was conducted using a differential refractive index (RI) and an ultraviolet (UV) detector set to $280 \mathrm{~nm}$. The analyses were performed in $\mathrm{CHCl}_{3}$ at $313 \mathrm{~K}$ and containing $0.5 \% \mathrm{w} / \mathrm{w}$ triethylamine $\left(\mathrm{Et}_{3} \mathrm{~N}\right)$ at a flow rate of $1.0 \mathrm{~mL} \mathrm{~min} \mathrm{~m}^{-1}$. Polystyrene (PS) $\left(162-2.4 \times 10^{5} \mathrm{~g} \mathrm{~mol}^{-1}\right)$ standards were used to calibrate the system. Molecular weights and dispersities were determined using Cirrus v2.2 SEC software.

IR spectroscopy was carried out using a Perkin Elmer Spectrum 100 FT-IR. 16 scans from 600 to $4000 \mathrm{~cm}^{-1}$ were taken, and the spectra corrected for background absorbance.

Mass spectra were acquired by matrix-assisted laser desorption and ionization time-of-flight mass spectrometry (MALDI-ToF MS) using a Bruker Daltonics Ultraflex Extreme MALDI-ToF mass spectrometer, equipped with a nitrogen laser delivering $3 \mathrm{~ns}$ laser pulses at $337 \mathrm{~nm}$. Solutions of DCTB as matrix $\left(30 \mathrm{~g} \mathrm{~L}^{-1}\right)$, NaTFA $\left(2 \mathrm{~g} \mathrm{~L}^{-1}\right)$ as cationization agent and polymer $\left(1 \mathrm{~g} \mathrm{~L}^{-1}\right)$ were prepared in THF. $20 \mu \mathrm{L}$ aliquots of matrix, polymer and NaTFA solutions were mixed in an Eppendorf tube then applied to the target followed by solvent evaporation to prepare a thin matrix/analyte film. The samples were measured in reflector mode.

\section{Synthetic procedures}

Synthesis of $\boldsymbol{O}$-hexyl-S-methyl 2-propionylxanthate (CTA 1). To a 3-neck $100 \mathrm{~mL}$ round bottom flask under a $\mathrm{N}_{2}$ atmos- 
phere was added $60 \mathrm{wt} \%$ sodium hydride $(1.75 \mathrm{~g}, 0.044 \mathrm{~mol})$. The vessel was cooled to $0{ }^{\circ} \mathrm{C}$ using an ice bath and dry THF $(50 \mathrm{~mL})$ was added via cannula transfer. After full addition of THF, 1-hexanol (4.07 g, $0.040 \mathrm{~mol}$ ) was added slowly, and then stirred at $0{ }^{\circ} \mathrm{C}$ for $10 \mathrm{~min}$ until no further outgassing was observed. Carbon disulfide (3.33 g, $0.044 \mathrm{~mol}$ ) was then added and the solution was stirred at $0{ }^{\circ} \mathrm{C}$ for $10 \mathrm{~min}$ and at room temperature for $1 \mathrm{~h}$. MBP $(7.30 \mathrm{~g}, 0.044 \mathrm{~mol})$ was then added directly and stirred for a further $2 \mathrm{~h}$. A white precipitate was observed to form upon stirring. The reaction was filtered to remove any formed salts then reduced in volume to dryness. The residue was then dissolved in ethyl acetate $(100 \mathrm{~mL})$ and washed with deionized water $(2 \times 100 \mathrm{~mL})$ and brine $(2 \times$ $100 \mathrm{~mL}$ ). The organic phase was dried over anhydrous magnesium sulfate, filtered and taken to dryness in vacuo. Column chromatography (silica gel, 19:1 petroleum spirit/EtOAc) afforded the target compound as a pale yellow oil (5.1 g, $48.0 \%) . \quad R_{\mathrm{f}}$ (9:1 petroleum spirit/EtOAc) $0.38 ;$ HRMS $\mathrm{m} / \mathrm{z}$ theory: 287.0746 $\left(\mathrm{M}-\mathrm{Na}^{+}\right)$; Found: 287.0749; Microanalysis: Calculated for $\mathrm{C}_{11} \mathrm{H}_{20} \mathrm{O}_{3} \mathrm{~S}_{2}$ : C, 49.97; H, 7.62; Found: C, 50.43; $\mathrm{H}, 7.66 \% .{ }^{1} \mathrm{H} \mathrm{NMR}\left(\mathrm{CDCl}_{3}\right): \delta 0.90\left(\mathrm{t}, 3 \mathrm{H},{ }^{3} J_{\mathrm{H}-\mathrm{H}}=6.8 \mathrm{~Hz}\right.$, $\left.\mathrm{CH}_{3} \mathrm{CH}_{2}\right), 1.25-1.48\left(\mathrm{~m}, 6 \mathrm{H}, \mathrm{CH}_{3}\left(\mathrm{CH}_{2}\right)_{3} \mathrm{CH}_{2}\right), 1.57$ (d, $3 \mathrm{H}$, $\left.{ }^{3} J_{\mathrm{H}-\mathrm{H}}=7.4 \mathrm{~Hz}, \mathrm{SCHCH}_{3}\right), 1.78\left(\mathrm{~m}, 2 \mathrm{H},{ }^{3} J_{\mathrm{H}-\mathrm{H}}=7.2 \mathrm{~Hz}\right.$, $\left.\mathrm{CH}_{2} \mathrm{CH}_{2} \mathrm{CH}_{2} \mathrm{O}\right), 3.75\left(\mathrm{~s}, 3 \mathrm{H},(\mathrm{C}=\mathrm{O}) \mathrm{OCH}_{3}\right), 4.41\left(\mathrm{q}, 1 \mathrm{H},{ }^{3} \mathrm{~J}_{\mathrm{H}-\mathrm{H}}=\right.$ $\left.7.4 \mathrm{~Hz}, \mathrm{SCHCH}_{3}\right), 4.56\left(\mathrm{t}, 2 \mathrm{H},{ }^{3} \mathrm{~J}_{\mathrm{H}-\mathrm{H}}=6.7 \mathrm{~Hz}, \mathrm{CH}_{2} \mathrm{CH}_{2} \mathrm{CH}_{2} \mathrm{O}\right)$; ${ }^{13} \mathrm{C}$ NMR $\left(\mathrm{CDCl}_{3}\right): \delta 212.3,172.0,74.7,52.9,47.1,31.5,28.2$, 25.7, 22.64, 17.1, 14.1 .

Synthesis of $\boldsymbol{O}$-p-methoxyphenyl-S-methylacetylxanthate (CTA 2). This synthesis is a modified version of the procedure published by Stenzel et al. ${ }^{44}$ To a $1000 \mathrm{~mL}$ Schlenk flask under $\mathrm{N}_{2}$ was added carbon disulfide $(250 \mathrm{~mL}, 4.16 \mathrm{~mol})$ and $p$-methoxyphenol (15.0 g, $0.12 \mathrm{~mol})$ which were stirred at $40{ }^{\circ} \mathrm{C}$ until dissolved. Triethylamine (17 mL, $0.12 \mathrm{~mol}$ ) was added and the reaction was stirred for $24 \mathrm{~h}$. MBA $(11.4 \mathrm{~mL}, 0.12 \mathrm{~mol})$ was added dropwise and the reaction was again stirred at $40{ }^{\circ} \mathrm{C}$ for $24 \mathrm{~h}$ whereby a precipitate formed. The unreacted carbon disulfide was then removed by vacuum transfer to leave a yellowish residue. This was then dissolved in $100 \mathrm{~mL}$ EtOAc, filtered to remove the $\mathrm{Et}_{3} \mathrm{~N} \cdot \mathrm{HBr}$ salts, and then washed with $\mathrm{H}_{2} \mathrm{O}$ (100 mL), $1 \mathrm{M} \mathrm{NaOH}(100 \mathrm{~mL}), 1 \mathrm{M} \mathrm{HCl}(100 \mathrm{~mL}), \mathrm{H}_{2} \mathrm{O}$ $(100 \mathrm{~mL})$, and finally brine $(100 \mathrm{~mL})$. The organic phase was dried over anhydrous magnesium sulfate, filtered and taken to dryness in vacuo. Column chromatography (silica gel, 100\% toluene) afforded the target compound as a pale yellow oil (9.9 g, 29.5\%). $R_{\mathrm{f}}$ (toluene) 0.2; HRMS $\mathrm{m} / \mathrm{z}$ theory: 295.0069 $\left(\mathrm{M}-\mathrm{Na}^{+}\right.$); Found: 295.0077; Microanalysis: Calculated for $\mathrm{C}_{11} \mathrm{H}_{12} \mathrm{O}_{4} \mathrm{~S}_{2}$ : C, 48.51; H, 4.44; Found: C, 48.21; H, 4.38\%. ${ }^{1} \mathrm{H}$ NMR $\left(\mathrm{CDCl}_{3}\right): \delta 3.80\left(\mathrm{~s}, 3 \mathrm{H}, \mathrm{ArOCH}_{3}\right), 3.81(\mathrm{~s}, 3 \mathrm{H},(\mathrm{C}=\mathrm{O})$ $\left.\mathrm{OCH}_{3}\right), 4.04\left(\mathrm{~s}, 2 \mathrm{H}, \mathrm{SCH}_{2}(\mathrm{C}=\mathrm{O}) \mathrm{O}\right), 6.9-7.1(\mathrm{Ar}, 4 \mathrm{H}) ;{ }^{13} \mathrm{C} \mathrm{NMR}$ $\left(\mathrm{CDCl}_{3}\right): \delta 213.1,168.1,157.9,148.1,122.7,114.5,55.6,53.0$, 38.7.

Synthesis of $\boldsymbol{O}$-isopropyl $\boldsymbol{S}$-methyl 2-propionylxanthate (CTA 4). To a 3-neck $100 \mathrm{~mL}$ round bottom flask under $\mathrm{N}_{2}$ was added sodium hydride (60 wt \% in mineral oil, $0.995 \mathrm{~g}, 2.5 \times$ $\left.10^{-2} \mathrm{~mol}\right)$. The vessel was then cooled to $0{ }^{\circ} \mathrm{C}$ using an ice bath and isopropanol (100 $\mathrm{mL})$ was added slowly, and then stirred at $0{ }^{\circ} \mathrm{C}$ for $15 \mathrm{~min}$ until no further outgassing was observed. Carbon disulfide $\left(1.65 \mathrm{~mL}, 2.7 \times 10^{-2} \mathrm{~mol}\right)$ was then slowly added, the solution turned yellow. The solution was stirred at room temperature for $30 \mathrm{~min}$, after which MBP $\left(2.8 \mathrm{~mL}, 2.5 \times 10^{-2} \mathrm{~mol}\right)$ was then added directly and stirred for $3 \mathrm{~h}$. A white precipitate was observed to form upon stirring. The reaction was then filtered to remove any formed salts then reduced in volume to dryness. Column chromatography (silica gel, 4:1 petroleum spirit/diethyl ether) afforded the target compound as a light yellow oil $(4.6 \mathrm{~g}, 83.7 \%) . R_{\mathrm{f}}(9: 1$ Hexane/ EtOAc) 0.34; HRMS $m / z$ theory: $245.0277\left(\mathrm{M}-\mathrm{Na}^{+}\right)$; Found: 245.0284; Microanalysis: Calculated for $\mathrm{C}_{9} \mathrm{H}_{16} \mathrm{O}_{3} \mathrm{~S}_{2}$ : C, 43.22; $\mathrm{H}, 6.35$; Found: C, 43.12; $\mathrm{H}, 6.26 \% ;{ }^{1} \mathrm{H} \mathrm{NMR}\left(\mathrm{CDCl}_{3}\right) \delta 1.37$ $\left(\mathrm{m}, 6 \mathrm{H},{ }^{3} J_{\mathrm{H}-\mathrm{H}}=6.0 \mathrm{~Hz}, \quad\left(\mathrm{CH}_{3}\right)_{2} \mathrm{CHO}\right), 1.55(\mathrm{~d}, 3 \mathrm{H}$, $\left.{ }^{3} J_{\mathrm{H}-\mathrm{H}}=7.4 \mathrm{~Hz}, \mathrm{CH}_{3} \mathrm{CHS}\right), 3.73\left(\mathrm{~s}, 3 \mathrm{H}, \mathrm{CH}_{3} \mathrm{OC}=\mathrm{O}\right), 4.35(\mathrm{~d}, 1 \mathrm{H}$, $\left.{ }^{3} J_{\mathrm{H}-\mathrm{H}}=7.4 \mathrm{~Hz}, \mathrm{CH}_{3} C H \mathrm{~S}\right), 5.71\left(\mathrm{~m}, 1 \mathrm{H},{ }^{3} J_{\mathrm{H}-\mathrm{H}}=6.2 \mathrm{~Hz}\right.$, $\left.\left(\mathrm{CH}_{3}\right)_{2} \mathrm{CHO}\right) ;{ }^{13} \mathrm{C} \mathrm{NMR}\left(\mathrm{CDCl}_{3}\right): \delta 211.2,172.1,78.5,52.8,46.7$, 21.3, 16.9 .

\section{General procedure for the synthesis of poly(VAc-co-MDO)}

In an inert environment, VAc $\left(1.55 \mathrm{~g}, 1.8 \times 10^{-2} \mathrm{~mol}\right)$, MDO $\left(0.228 \mathrm{~g}, 2.0 \times 10^{-3} \mathrm{~mol}\right)$, CTA $2\left(55.5 \mathrm{mg}, 2.0 \times 10^{-4} \mathrm{~mol}\right)$, $\operatorname{ABCN}\left(4.9 \mathrm{mg}, 2.0 \times 10^{-5} \mathrm{~mol}\right)$ and $\mathrm{C}_{6} \mathrm{D}_{6}(15 \mathrm{~mol} \%)$ were placed into a Young's tapped ampoule and sealed. The solution was subjected to a further 3 freeze-pump-thaw cycles then backfilled with argon. The resulting solution was stirred and heated to $90{ }^{\circ} \mathrm{C}$ for $4 \mathrm{~h}$ before the polymerization was quenched by plunging the ampoule into an ice bath. An aliquot was taken prior to precipitation for conversion by ${ }^{1} \mathrm{H}$ NMR spectroscopy $\left(\mathrm{CDCl}_{3}\right.$ was pre-treated by passage through basic $\mathrm{Al}_{2} \mathrm{O}_{3}$ to remove any acids present). The polymer was then dissolved in $\mathrm{CHCl}_{3}$ and precipitated several times into hexane until no further monomer residue was observed. The final light yellow solid was dried under vacuum at room temperature for $24 \mathrm{~h}$. Conversion: VAc $=58 \%$; $\mathrm{MDO}=51 \%$. SEC $\left(\mathrm{CHCl}_{3}+0.5 \% \mathrm{w} / \mathrm{w} \mathrm{Et}{ }_{3} \mathrm{~N}\right): M_{\mathrm{n}}=8.1 \mathrm{kDa}, \oplus_{\mathrm{M}}=1.38$.

\section{General procedure for the synthesis of poly(MDO)}

In an inert environment, $\mathrm{MDO}\left(2.28 \mathrm{~g}, 2.0 \times 10^{-2} \mathrm{~mol}\right)$, CTA 2 (55.5 mg, $2.0 \times 10^{-4} \mathrm{~mol}$ ), $\mathrm{ABCN}\left(4.9 \mathrm{mg}, 2.0 \times 10^{-5} \mathrm{~mol}\right)$ and $\mathrm{C}_{6} \mathrm{D}_{6}(15 \mathrm{~mol} \%)$ were placed into a Young's tapped ampoule and sealed. The solution was subjected to a further 3 freezepump-thaw cycles then backfilled with argon. The resulting solution was stirred and heated to $90{ }^{\circ} \mathrm{C}$ for $24 \mathrm{~h}$ before the polymerization was quenched by plunging the ampoule into an ice bath. An aliquot was taken prior to precipitation for conversion by ${ }^{1} \mathrm{H}$ NMR spectroscopy $\left(\mathrm{CDCl}_{3}\right.$ was pre-treated by passage through basic $\mathrm{Al}_{2} \mathrm{O}_{3}$ to remove any acids present). The polymer was then dissolved in $\mathrm{CHCl}_{3}$ and precipitated several times into hexane until no further monomer residue was observed. The final light yellow solid was dried under vacuum at room temperature for $24 \mathrm{~h}$. Conversion: 22\%. SEC $\left(\mathrm{CHCl}_{3}+\right.$ $\left.0.5 \% \mathrm{w} / \mathrm{w} \mathrm{Et}_{3} \mathrm{~N}\right): M_{\mathrm{n}}=3.9 \mathrm{kDa}, \bigoplus_{\mathrm{M}}=1.55$. 
General procedure for in situ aminolysis and Michael addition to form poly(MDO)-S-alkyne

Poly(MDO) derived from CTA $2\left(200.0 \mathrm{mg}, 7.2 \times 10^{-5} \mathrm{~mol}\right.$, $\left.M_{\mathrm{n}, \mathrm{NMR}}=1.7 \mathrm{kDa}, \emptyset_{\mathrm{M}}=1.44\right)$, TCEP. $\mathrm{HCl}\left(3.0 \mathrm{mg}, 1.4 \times 10^{-5}\right.$ $\mathrm{mol})$, propargyl methacrylate $\left(90.0 \mathrm{mg}, 7.3 \times 10^{-4} \mathrm{~mol}\right)$ and DMF $(1 \mathrm{~mL})$ were placed into a Schlenk flask and sealed. The solution was then degassed by 3 consecutive freeze-pumpthaw cycles. Hexylamine $\left(47 \mu \mathrm{L}, 3.6 \times 10^{-4} \mathrm{~mol}\right)$ was added under $\mathrm{N}_{2}$ flow and the solution was degassed once more by freeze-pump-thaw, backfilled with $\mathrm{N}_{2}$, and allowed to stir at room temperature for $36 \mathrm{~h}$. The polymer was then precipitated several times from $\mathrm{CHCl}_{3}$ into cold diethyl ether/ethanol $(1: 1)$. The final pale yellow residue was dried under vacuum at room temperature for $24 \mathrm{~h}$. SEC $\left(\mathrm{CHCl}_{3}+0.5 \% \mathrm{w} / \mathrm{w} \mathrm{Et}{ }_{3} \mathrm{~N}\right): M_{\mathrm{n}}=$ $4.0 \mathrm{kDa}, \emptyset_{\mathrm{M}}=1.36$.

\section{Results and discussion}

We have previously demonstrated the utility of CTA 1 (Fig. 1) for the synthesis of copolymers of VAc and MDO. We noted however that at high incorporations of MDO, the polymers displayed increased dispersity and loss of end-group fidelity at extended times. ${ }^{22}$ In order to further investigate the mechanism for this loss of end-group and in turn, increase control over the copolymerization and extend the methodology to MDO homopolymerization, we sought to modify the structure of the xanthate chain transfer agent (Fig. 1).

We hypothesized that the incorporation of a primary leaving group adjacent to the xanthate, introduced by the ringopened MDO, forces the xanthate radical intermediate to

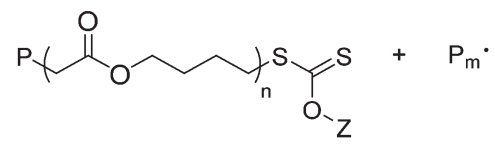

Xanthate end group functionality

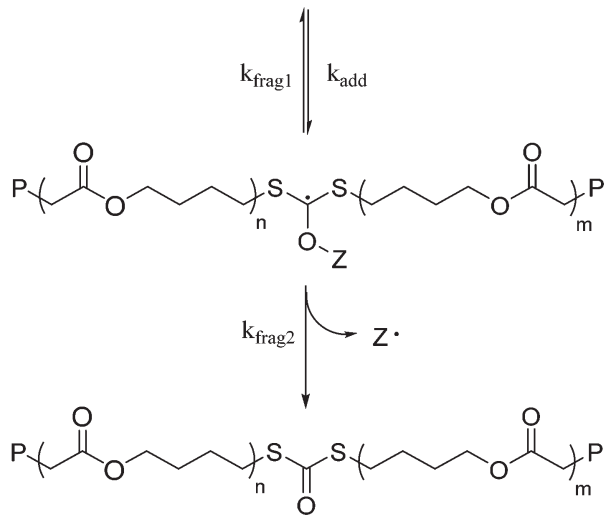

Carbonodithioate mid-chain functionality

Scheme 1 Rearrangement and Z-group fragmentation occurring during the polymerization of MDO in the presence of a xanthate.
CTA 1

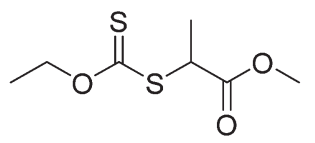

CTA 3<smiles>COC(=O)C(C)SC(=S)OCC(C)(C)C</smiles><smiles>COC(=O)CSC(=S)Oc1ccc(OC)cc1</smiles>

CTA 2<smiles>COC(=O)C(C)SC(=S)OC(C)C</smiles>

CTA 4
Fig. 1 Structure of all xanthates used for the (co)polymerisation of MDO.

fragment via the Z-group (Scheme 1), which has previously been observed by Dommanget et al. for xanthate-mediated ethylene polymerizations. ${ }^{45}$ In an attempt to reduce and even negate this for VAc/MDO copolymerizations, we investigated xanthate design, specifically to target a xanthate in which the Z-group contains a phenyl moiety that would be less likely to stabilize a radical through the proposed Z-group fragmentation mechanism and allow for conventional fragmentation of the dormant polymer chain. To this end, CTA 2, previously reported by Stenzel et al. to polymerize VAc over a range of molecular weights from $M_{\mathrm{n}}=1-50 \mathrm{kDa},{ }^{44}$ provided an ideal candidate. CTA 2 was synthesized as reported previously. Optimization of the purification method was required to remove an impurity, identified as the direct addition of MBA onto $p$-methoxyphenol, running at the same $R_{\mathrm{f}}$ as the product.

\section{VAc/MDO copolymerization}

In order to test the efficacy of CTA 2 in the copolymerization of VAc and MDO, we emulated the conditions that we had reported previously. ${ }^{22}$ Monomer ratios of 70:30 and 30:70 VAc: $\mathrm{MDO}$ were polymerized for $24 \mathrm{~h}$ at $60{ }^{\circ} \mathrm{C}$ in $15 \mathrm{~mol} \%$ $\mathrm{C}_{6} \mathrm{D}_{6}$. Analysis by ${ }^{1} \mathrm{H}$ NMR spectroscopic measurements showed low monomer conversions were achieved, with 70:30 VAc: MDO monomer ratio only reaching 17 and 12\% conversion for VAc and MDO respectively, and 30:70 VAc:MDO monomer ratio only reaching monomer conversions of $7 \%$ and $4 \%$. We hypothesized this was due to low fragmentation rate of the xanthate from the dormant polymer chain. In an attempt to increase this fragmentation rate and hence monomer conversions, ABCN (Vazo 88) replaced AIBN as the initiating species and the reaction temperature was increased to $90{ }^{\circ} \mathrm{C}$. In this fashion, monomer feed ratios of $90: 10,70: 30,50: 50$, and 30:70 for VAc: MDO respectively were polymerized targeting an overall degree of polymerization (DP) of 100 (Table 1, entries 2-5).

As the MDO ratio was increased, longer polymerization times were required to achieve VAc conversions between $55-65 \%$, and MDO conversions were reduced from 51 to $29 \%$. These increased polymerization times are most likely due to 
Table 1 Copolymerization of VAc and MDO with CTA 2 using different feed ratios ${ }^{a}$

\begin{tabular}{|c|c|c|c|c|c|c|c|c|}
\hline $\begin{array}{l}\text { Time } \\
\text { (h) }\end{array}$ & $\begin{array}{l}\text { Monomer feed } \\
\text { (VAc/MDO) }\end{array}$ & $\begin{array}{l}\text { Monomer incorp. }{ }^{b} \\
\text { (VAc/MDO) }\end{array}$ & $\begin{array}{l}\text { VAc conv. } \\
(\%)\end{array}$ & $\begin{array}{l}\text { MDO conv. } \\
(\%)\end{array}$ & $\begin{array}{l}M_{\mathrm{n}}^{\mathrm{obs} c} \\
(\mathrm{kDa})\end{array}$ & $\begin{array}{l}M_{\mathrm{n}}^{\mathrm{SEC} d} \\
(\mathrm{kDa})\end{array}$ & $\begin{array}{l}M_{\mathrm{n}}^{\text {theor } e} \\
(\mathrm{kDa})\end{array}$ & $D_{M}{ }^{d}$ \\
\hline 1.25 & $100: 0$ & $100: 0$ & 62 & - & 7.0 & 7.7 & 5.6 & 1.27 \\
\hline 15 & $70: 30$ & $79: 21$ & 65 & 41 & 8.2 & 7.9 & 5.6 & 1.35 \\
\hline 15 & $50: 50$ & $66: 34$ & 55 & 30 & 6.5 & 7.2 & 4.4 & 1.32 \\
\hline 24 & $30: 70$ & $46: 54$ & 55 & 29 & 6.3 & 5.7 & 4.2 & 1.43 \\
\hline 24 & $0: 100$ & $0: 100$ & - & 22 & 4.5 & 3.9 & 2.8 & 1.55 \\
\hline
\end{tabular}

${ }^{a}$ Conditions: 15 mol\% $\mathrm{C}_{6} \mathrm{D}_{6}, 90{ }^{\circ} \mathrm{C}$, [monomers]: [CTA 2] : [ABCN] = $100: 1: 0.1 .{ }^{b}$ Calculated from ${ }^{1} \mathrm{H}$ NMR spectroscopy. ${ }^{c}$ Observed molecular weight obtained by ${ }^{1} \mathrm{H}$ NMR spectroscopy end-group analysis, calibrated from aromatic peaks to $4 \mathrm{H} .{ }^{d}$ Observed molecular weight and dispersity obtained by SEC analyses in $\mathrm{CHCl}_{3} .{ }^{e}$ Theoretical molecular weight based on monomer conversion $\left({ }^{1} \mathrm{H}\right.$ NMR spectroscopy).

the lower fragmentation rate of the xanthate from the dormant polymer chains that have an MDO repeat unit adjacent to the xanthate. These copolymerization kinetic features were similar to a related study conducted by d'Ayala et al. for the copolymerization of VAc with 5,6-benzo-2-methylene-1,3-dioxepane (BMDO, a related CKA monomer). ${ }^{46} M_{\mathrm{n}}^{\mathrm{obs}}$ matched well with $M_{\mathrm{n}}^{\mathrm{SEC}}$ but both were consistently higher than $M_{\mathrm{n}}^{\text {theor }}$, which suggests that some termination occurs during the polymerization. All dispersities $\left(\emptyset_{\mathrm{M}}\right)$ for these polymers were within 1.3-1.5, which is typical for xanthate polymerizations as a consequence of their low transfer rates. ${ }^{47}$ Analysis of molecular weight distributions from SEC (Fig. 2) showed that all copolymers have monomodal distributions, and the overlaid UV traces taken at $280 \mathrm{~nm}$ show the presence of the xanthate chain-end throughout the whole distribution. The UV traces also tend to shift towards higher molecular weight with increased MDO content, most likely a result of increasing termination events that result in loss of the xanthate chain-end and lower molecular weight tailing.

As a control, VAc was also homopolymerized (Table 1, entry 1) under the same conditions. The polymerization time was kept to $1.25 \mathrm{~h}$ so that the monomer conversion was similar to those in the copolymer syntheses. Analysis of the ${ }^{1} \mathrm{H}$ NMR spectrum and SEC chromatogram showed $M_{\mathrm{n}}^{\mathrm{obs}}=7.0 \mathrm{kDa}$ to be in agreement with $M_{\mathrm{n}}^{\mathrm{SEC}}=7.7 \mathrm{kDa}$, which again was slightly higher than $M_{\mathrm{n}}^{\text {theor }}$. The monomodal chromatogram displayed a $\emptyset_{M}=1.27$, which is comparable to previous reports of poly(VAc) synthesized this way. ${ }^{44}$

Analysis of all copolymers by ${ }^{1} \mathrm{H}$ NMR spectroscopy (see ESI $\dagger$ ) showed clear evidence of aromatic peaks associated with the Z- group from the xanthate CTA 2 at $\delta=6.9-7.0 \mathrm{ppm}$ as well as the methoxy peak at $\delta=3.8 \mathrm{ppm}$ from the R-group. A comparison of all ${ }^{1} \mathrm{H}$ NMR spectra (see ESI, Fig. S25 $\dagger$ ) showed that as the VAc content in the copolymers decreased, the VAc peak intensity at $\delta=5.0 \mathrm{ppm}$ also decreased, and the intensity of the peak associated with MDO at $\delta=4.2 \mathrm{ppm}$ increased as expected. Also, at higher MDO content, the intensity of VAcMDO diad at $\delta=5.2 \mathrm{ppm}$ increased and the intensity of VAcVAc diad at $\delta=4.9 \mathrm{ppm}$ decreased, which indicates that an increased content of MDO is incorporated into the polymer backbone. However, as the content of MDO increased, there was also evidence of increased side reactions present, with a peak at $\delta=6.7 \mathrm{ppm}$ whose intensity was increased in polymers with higher MDO content. We postulate that this resonance occurs as a consequence of the proposed Z-group fragmentation that would result in a $p$-methoxyphenyl radical that could reinitiate or terminate polymer chains. Additionally, peaks associated with backbiting side reactions at $\delta=0.9,3.15$ and $3.65 \mathrm{ppm}$ were observed. There was no evidence of the methine proton of VAc adjacent to the xanthate chain-end, however there was a peak at $\delta=3.2 \mathrm{ppm}$ that is consistent with the $\mathrm{CH}_{2}$ resonance from MDO adjacent to a xanthate; the integration of which was approximately 2 for all copolymers. This would suggest that all dormant polymer chains have the xanthate attached to a terminal MDO unit, not to a VAc unit, which would be a result of the slow fragmentation rate from the MDO alkyl chain to form a reactive radical species and is comparable to the observations by Dommanget et al. in the RAFT/MADIX-mediated copolymerization of VA and ethylene. ${ }^{45,48}$ Further analysis of ${ }^{13} \mathrm{C}$ NMR spectra of the copolymers (see ESI $\dagger$ ) also showed evidence of xanthate chain-end retention, in particular peaks associated with the aromatic group $(\delta=114,123,148$ and $158 \mathrm{ppm})$, the methoxy peak at $\delta=56 \mathrm{ppm}$, as well as the dithiocarbonate peak at $\delta=215 \mathrm{ppm}$. There was also no evidence of an acetal peak at $\delta=100 \mathrm{ppm}$ which would arise from the incorporation of ring-retained MDO within the copolymer.

\section{MDO homopolymer synthesis and comparison with other CTAS}

As well as conducting VAc/MDO copolymerizations, the homopolymerization of MDO was also trialled using CTA 2, (Table 1, entry 6). Following polymerization under identical conditions as outlined above, SEC and ${ }^{1} \mathrm{H}$ NMR spectroscopic analysis showed $M_{\mathrm{n}}^{\mathrm{obs}}=4.5 \mathrm{kDa}$ to be in agreement with $M_{\mathrm{n}}^{\mathrm{SEC}}=$ $3.9 \mathrm{kDa}$. While this was again slightly higher than $M_{\mathrm{n}}^{\text {theor }}$, the dispersity remained low, $\emptyset_{\mathrm{M}}=1.55$ and the molecular weight distribution was monomodal with a low molar mass tail (Fig. 2). The overlaid RI and UV traces taken at $280 \mathrm{~nm}$ showed the presence of the phenyl moiety of the xanthate on the chain-end throughout the whole distribution, albeit shifted to higher molecular weight as a result of the "dead" chains not containing the UV-active xanthate end-group. To further 
100:0

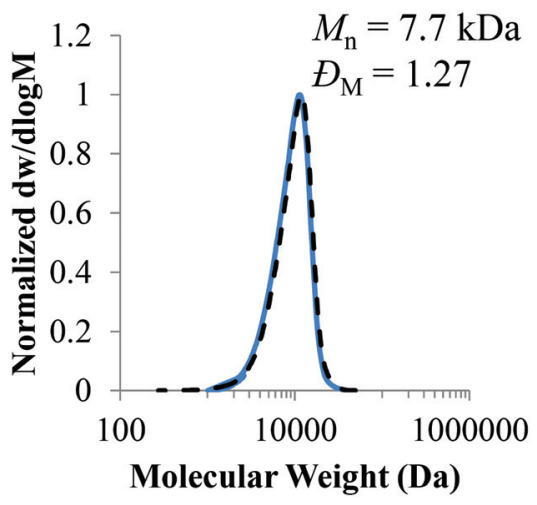

$50: 50$

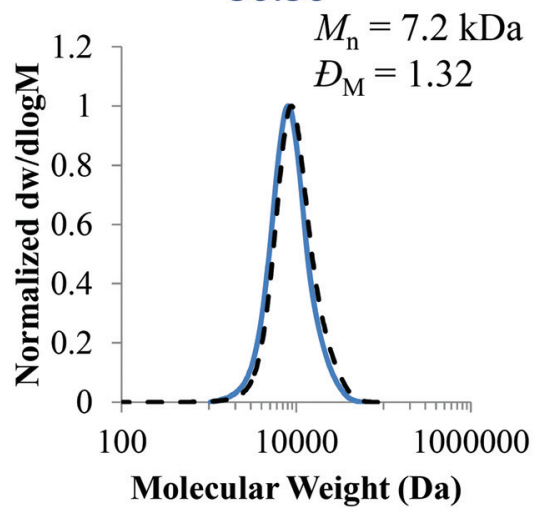

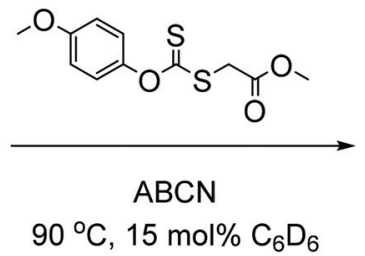

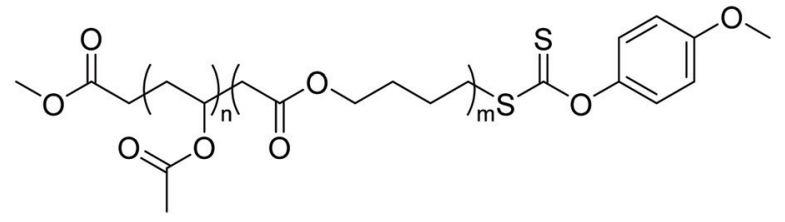

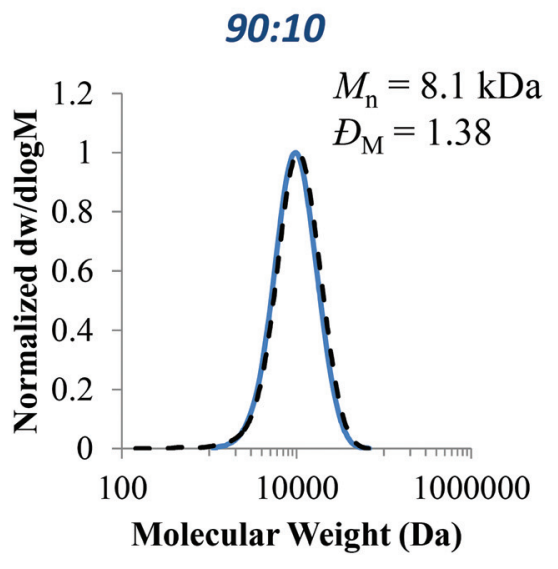

30:70

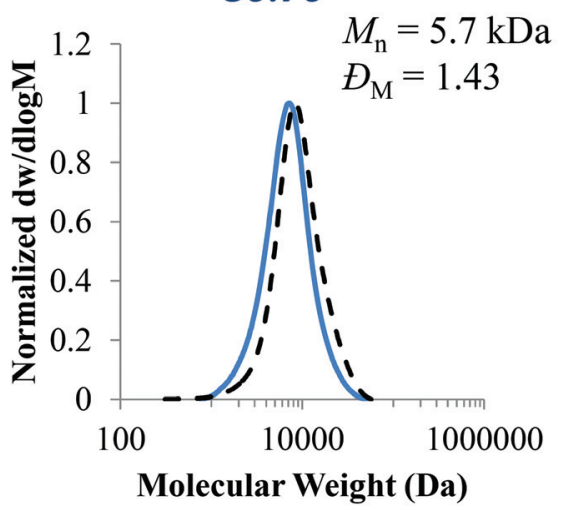

70:30

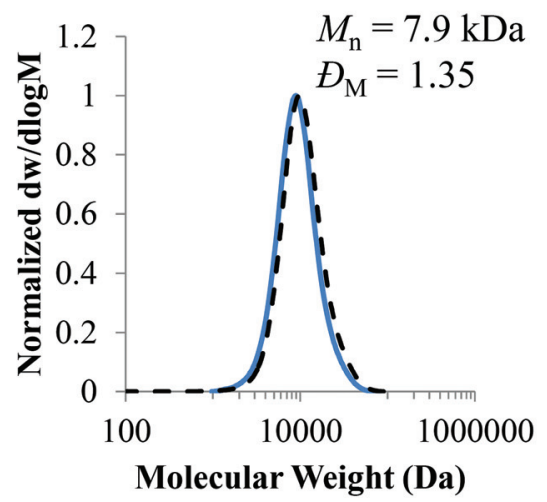

$0: 100$

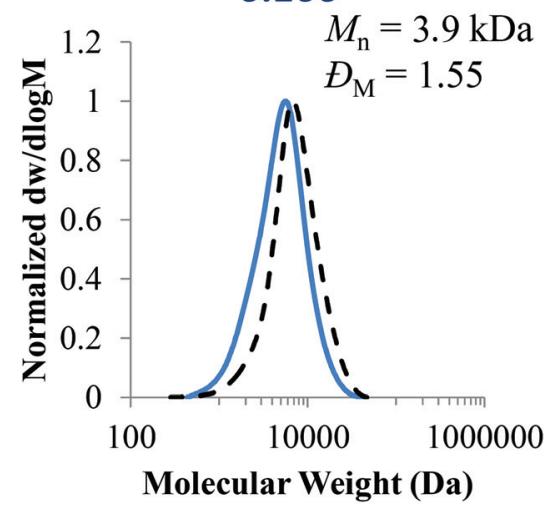

Fig. 2 General scheme for the xanthate mediated copolymerizations of VAc and MDO with CTA 2 using different ratios of VAC: MDO with their associated SEC chromatograms. Dashed lines indicate molecular weight distribution from UV@280 nm (adjusted to the weight distribution).

confirm our hypothesis that the suppression of fragmentation of the xanthate radical intermediate via the Z-group can be achieved by incorporation of a phenyl Z-group, three other xanthates were tested in the polymerization of MDO (Fig. 1). CTA 1 was tested as this was the xanthate used in our previous study of VAc/MDO copolymerizations, whereas CTA 3 was used primarily as a control due to its success in mediating the polymerization of LAMs such as vinyl acetate. ${ }^{49,50}$ Finally, CTA 4 was synthesized incorporating an isopropyl Z-group in an endeavour to increase Z-group fragmentation through the generation of a more stable secondary alkyl radical. Homopolymerizations of MDO mediated with CTAs 1-4 all targeted a final degree of polymerization (DP) of 50 and were reacted for $24 \mathrm{~h}$ at $60^{\circ} \mathrm{C}$, with the exception of CTA 2 which was reacted at $90{ }^{\circ} \mathrm{C}$ to enhance conversion as no polymerization occurs at $60{ }^{\circ} \mathrm{C}$ (Table 2). Monomer conversions were similar for all four xanthates, only varying from $17-21 \%$, and the number-average
Table 2 Characterization data for the homopolymer, poly(MDO), mediated by all CTAs (conditions: 15 mol\% $\mathrm{C}_{6} \mathrm{D}_{6}, 60^{\circ} \mathrm{C}$, [monomers] : $[C T A]:[A I B N]=50: 1: 0.1)$

\begin{tabular}{lllllll}
\hline CTA & $\begin{array}{l}\text { MDO } \\
\text { conv. }(\%)\end{array}$ & $\begin{array}{l}M_{\mathrm{n}}{ }^{\text {obs. } b} \\
(\mathrm{kDa})\end{array}$ & $\begin{array}{l}M_{\mathrm{n}}^{\mathrm{SEC} c} \\
(\mathrm{kDa})\end{array}$ & $\begin{array}{l}M_{\mathrm{n}}^{\text {theo. } d} \\
(\mathrm{kDa})\end{array}$ & $\bigoplus_{\mathrm{M}}{ }^{e}$ & $\mathrm{UV}^{f}$ \\
\hline 1 & 20.0 & 17.7 & 4.2 & 1.4 & 1.55 & Weak \\
2 & 1.8 & - & - & 0.4 & - & - \\
$2^{a}$ & 16.7 & 1.7 & 2.8 & 1.1 & 1.44 & Strong \\
3 & 21.9 & 6.0 & 2.8 & 1.5 & 1.58 & Weak \\
4 & 21.3 & 9.5 & 5.2 & 1.4 & 1.90 & V. Weak
\end{tabular}

${ }^{a}$ Polymerization was conducted at $90{ }^{\circ} \mathrm{C}$ using $\mathrm{ABCN}$ as the initiator. ${ }^{b}$ Observed molecular weight obtained by ${ }^{1} \mathrm{H}$ NMR spectroscopy endgroups analysis. ${ }^{c}$ Observed molecular weight obtained by SEC analyses in $\mathrm{CHCl}_{3}$. ${ }^{d}$ Theoretical molecular weight based on monomer conversion ( ${ }^{1} \mathrm{H}$ NMR). ${ }^{e}$ Dispersities obtained by SEC analyses in $\mathrm{CHCl}_{3} .{ }^{f}$ SEC UV analysis at $280 \mathrm{~nm}$ - for SEC chromatograms see Fig. S45. 
molecular weights $\left(M_{\mathrm{n}}\right)$ determined by SEC varied from 2.8-5.2 kDa. However, poly-(MDO) mediated with CTA 4 showed a much broader dispersity of 1.90 compared to that observed for poly(MDO) mediated with CTAs $\mathbf{1}$ and 3; poly(MDO) mediated with CTA 2 at $90{ }^{\circ} \mathrm{C}$ showed the lowest dispersity, $\emptyset_{\mathrm{M}}=1.44$. Analysis of the SEC UV chromatograms at $280 \mathrm{~nm}$ also showed a very small peak for poly(MDO) mediated with CTA 4, yet $\mathbf{1}$ and $\mathbf{3}$ displayed stronger UV responses, which confirms greater retention of the xanthate end-group (Fig. S45†). Again, poly(MDO) mediated with CTA 2 displayed the strongest UV chromatographic peak. These observations were further corroborated by analysis of the ${ }^{1} \mathrm{H}$ NMR spectra for all four polymers (Fig. S30, S35, S40 and S43†) in which poly(MDO) mediated with CTA 2 displayed a very high retention of the xanthate chain-end, whereas poly-(MDO) mediated with CTAs 1, 3, and 4 retained a lower amount of Z-group functionality. More in depth analysis of the polymer chain-ends by ${ }^{13} \mathrm{C}$ NMR spectroscopy was able to further probe the retention of xanthate at the chain-end by comparison of the resonance at $\delta=214 \mathrm{ppm}$ (attributed to the xanthate carbonyl) with that of a resonance at $\delta=189 \mathrm{ppm}$ that is attributed to the formation of a carbonodithioate carbonyl, ${ }^{51,52}$ consistent with our hypothesis of Z-group fragmentation and electron rearrangement. Most notably, poly(MDO) mediated with CTA 4 displayed a complete loss of the xanthate carbon peak (Fig. S44 $\dagger$ ) whereas poly(MDO) mediated with CTAs 1, 2 and 3 showed both the xanthate carbonyl peak and carbonodithioate carbonyl peak (Fig. S31, S36 and S41† respectively) with the polymer from CTA 2 resulting in the highest retention of xanthate end-group.

Poly(MDO) mediated with CTAs 1 and 2 were also analysed by MALDI-ToF MS in reflector mode to further quantify the level of retention of xanthate on the polymer chain-end. The mass distribution for poly(MDO) mediated with CTA 2 (Fig. S37 $\dagger$ ) shows a major peak that belongs to sodiumcharged poly(MDO) initiated with the R-group and terminated with the Z-group of CTA 2, with each peak separated by the molecular weight of MDO. Also present is a small distribution attributed to $\mathrm{ABCN}$ radical initiation and side reactions that occur during the polymerization process (Fig. S38†). In comparison, the mass distribution for poly(MDO) mediated with CTA 1 (Fig. S32†) reveals 3 distinct polymer distributions, with the major distribution corresponding to the carbonodithioate polymer species that arises from Z-group fragmentation of the polymer-polymer radical intermediate during the RAFT process. Also present in this distribution are dormant polymer chains that incorporate the intact CTA (Fig. S33†). These data again corroborate the evidence of $p$-methoxyphenyl xanthate retention from SEC and ${ }^{1} \mathrm{H}$ NMR spectroscopy.

Post-polymerization functionalization of the terminal xanthate by in situ aminolysis and Michael addition

As final proof of the retention of CTA 2 on the polymer chainend of poly(MDO $)_{14}$, an in situ aminolysis and Michael addition experiment was performed using hexylamine and propargyl methacrylate in DMF. This post-polymerization modifi- cation was achieved by aminolysis of the xanthate to form the terminal thiol (in the presence of TCEP.HCl to reduce any disulfides that formed) whilst in the presence of propargyl methacrylate that reacts via base-catalyzed Michael addition onto the thiol in situ. SEC analysis shows the peak to be monomodal suggesting no deleterious side reactions occurred during the modification. ${ }^{1} \mathrm{H}$ NMR spectroscopic analysis shows complete removal of the xanthate chain-end with the loss of the aromatic peaks at $\delta=7.0 \mathrm{ppm}$ and the methoxy peak at $\delta=$ $3.8 \mathrm{ppm}$ (Fig. S47†). This is corroborated by ${ }^{13} \mathrm{C}$ NMR spectroscopy which also shows the loss of the resonance attributed to the thiocarbonyl xanthate at $\delta=215$ ppm (Fig. S48 $\dagger$ ). Further evidence of chain-end modification comes from comparison of the MALDI-ToF mass spectra before and after aminolysis/Michael addition (Fig. S37 and S49†). The isotopic mass distribution obtained from reflector mode of the modified poly(MDO) shows the major species present to belong to a sodium-charged poly(MDO) functionalized with propargyl methacrylate added onto the terminal thiol from the xanthate chain-end.

\section{Conclusions}

In summary, we report the copolymerization of VAc and MDO, as well as the homopolymerization of MDO in the presence of CTA 2. Initial results revealed that this xanthate offers significantly enhanced control over molecular weight and dispersity than other xanthates that have been reported for mediating the rROP of MDO. This xanthate also exhibits high retention onto the polymer chain-end for all copolymers as well as poly(MDO), as demonstrated by MALDI-ToF MS analysis and modification of the chain-end through post-polymerization aminolysis and Michael addition of propargyl methacrylate. MDO homopolymerizations mediated with other known xanthates showed decreased retention of the xanthate chain-end. We were able to confirm that loss of control of the polymerization and loss of end-group fidelity were a result of Z-group fragmentation and rearrangement to form the carbonodithioate functionality.

\section{Acknowledgements}

The University of Warwick and BP are thanked for co-funding a Ph.D. studentship to G.G.H and the Royal Society and British academy are thanked for the award of a Newton International Fellowship to C.A.B and Industry Fellowship to A.P.D. EPSRC are also acknowledged for funding to support R.K.O. (Career Acceleration Fellowship). NHMRC are thanked for the award of a C.J. Martin Early Career International Fellowship to C.A.B.

\section{Notes and references}

1 W. J. Bailey, Z. Ni and S.-R. Wu, J. Polym. Sci., Part A: Polym. Chem., 1982, 20, 3021-3030. 
2 S. Agarwal, Polym. Chem., 2010, 1, 953-964.

3 P. Plikk, T. Tyson, A. Finne-Wistrand and A.-C. Albertsson, J. Polym. Sci., Part A: Polym. Chem., 2009, 47, 4587-4601.

4 T. Endo, M. Okawara, W. J. Bailey, K. Azuma, K. Nate and H. Yokono, J. Polym. Sci., Polym. Lett. Ed., 1983, 21, 373380.

5 W. J. Bailey, Z. Ni and S. R. Wu, Macromolecules, 1982, 15, 711-714.

6 W. J. Bailey, S.-R. Wu and Z. Ni, Macromol. Chem. Phys., 1982, 183, 1913-1920.

7 N. Grabe, Y. Zhang and S. Agarwal, Macromol. Chem. Phys., 2011, 212, 1327-1334.

8 Q. Jin, S. Maji and S. Agarwal, Polym. Chem., 2012, 3, 27852793.

9 S. Theiler, M. Teske, H. Keul, K. Sternberg and M. Moller, Polym. Chem., 2010, 1, 1215-1225.

10 A. K. Bassi, J. E. Gough, M. Zakikhani and S. Downes, J. Tissue Eng., 2011, 615328.

11 J. Zhou, W. Wang, S. Villarroya, K. J. Thurecht and S. M. Howdle, Chem. Commun., 2008, 5806-5808.

12 M. Labet and W. Thielemans, Chem. Soc. Rev., 2009, 38, 3484-3504.

13 J. N. Hoskins and S. M. Grayson, Polym. Chem., 2011, 2, 289-299.

14 B. Wu and R. W. Lenz, J. Environ. Polym. Degrad., 1998, 6, 23-29.

15 W. J. Bailey, T. Endo, B. Gapud, Y. N. Lin, Z. Ni, C. Y. Pan, S. E. Shaffer, S. R. Wu, N. Yamazaki and K. Yonezawa, J. Macromol. Sci., Chem., 1984, A21, 979-995.

16 W. J. Bailey, V. K. Kuruganti and J. S. Angle, ACS Symp. Ser., 1990, 433, 149-160.

17 L. M. Morris, T. P. Davis and R. P. Chaplin, Polymer, 2000, 42, 495-500.

18 J. Xu, Z.-L. Liu and R.-X. Zhuo, J. Appl. Polym. Sci., 2007, 103, 1146-1151.

19 V. Delplace, A. Tardy, S. Harrisson, S. Mura, D. Gigmes, Y. Guillaneuf and J. Nicolas, Biomacromolecules, 2013, 14, 3769-3779.

20 V. Delplace, S. Harrisson, A. Tardy, D. Gigmes, Y. Guillaneuf and J. Nicolas, Macromol. Rapid Commun., 2014, 35, 484-491.

21 S. Agarwal, R. Kumar, T. Kissel and R. Reul, Polym. J., 2009, 41, 650-660.

22 G. G. Hedir, C. A. Bell, N. S. Ieong, E. Chapman, I. R. Collins, R. K. O'Reilly and A. P. Dove, Macromolecules, 2014, 47, 2847-2852.

23 J. Undin, T. Illanes, A. Finne-Wistrand and A.-C. Albertsson, Polym. Chem., 2012, 3, 1260-1266.

24 S. Agarwal, Polym. J., 2007, 39, 163-174.

25 G. E. Roberts, M. L. Coote, J. P. A. Heuts, L. M. Morris and T. P. Davis, Macromolecules, 1999, 32, 1332-1340.

26 T. Cai, Y. Chen, Y. Wang, H. Wang, X. Liu, Q. Jin, S. Agarwal and J. Ji, Macromol. Chem. Phys., 2014, 215, 1848-1854.
27 S. Louguet, V. Verret, L. Bedouet, E. Servais, F. Pascale, M. Wassef, D. Labarre, A. Laurent and L. Moine, Acta Biomater., 2014, 10, 1194-1205.

28 S. Agarwal and L. Ren, PMSE Prepr., 2009, 100, 89-90.

29 S. Maji, F. Mitschang, L. Chen, Q. Jin, Y. Wang and S. Agarwal, Macromol. Chem. Phys., 2012, 213, 1643-1654.

30 Y. Zhang, A. Aigner and S. Agarwal, Macromol. Biosci., 2013, 13, 1267-1275.

31 A. Galperin, T. J. Long and B. D. Ratner, Biomacromolecules, 2010, 11, 2583-2592.

32 L.-F. Sun, R.-X. Zhuo and Z.-l. Liu, Macromol. Biosci., 2003, 3, 725-728.

33 S. Choi, K. Lee, S. Kwon and H. Kim, J. Supercrit. Fluids, 2006, 37, 287-291.

34 S. Kwon, K. Lee, W. Bae and H. Kim, Polym. J., 2008, 40, 332-338.

35 L. F. Sun, R. X. Zhuo and Z. L. Liu, J. Polym. Sci., Part A: Polym. Chem., 2003, 41, 2898-2904.

36 A. Tardy, V. Delplace, D. Siri, C. Lefay, S. Harrisson, B. de Fatima Albergaria Pereira, L. Charles, D. Gigmes, J. Nicolas and Y. Guillaneuf, Polym. Chem., 2013, 4, 4776-4787.

37 J. Huang, R. Gil and K. Matyjaszewski, Polymer, 2005, 46, 11698-11706.

38 H. Wickel, S. Agarwal and A. Greiner, Macromolecules, 2003, 36, 2397-2403.

39 J.-Y. Yuan, C.-Y. Pan and B. Z. Tang, Macromolecules, 2001, 34, 211-214.

40 T. He, Y.-F. Zou and C.-Y. Pan, Polym. J., 2002, 34, 138-143.

41 Y. Wei, E. J. Connors, X. Jia and B. Wang, Chem. Mater., 1996, 8, 604-606.

42 Y. Wei, E. J. Connors, X. Jia and B. Wang, J. Polym. Sci., Part A: Polym. Chem., 1998, 36, 761-771.

43 J. Skey and R. K. O'Reilly, Chem. Commun., 2008, 41834185.

44 M. H. Stenzel, L. Cummins, G. E. Roberts, T. P. Davis, P. Vana and C. Barner-Kowollik, Macromol. Chem. Phys., 2003, 204, 1160-1168.

45 C. Dommanget, F. D'Agosto and V. Monteil, Angew. Chem., Int. Ed., 2014, 53, 6683-6686.

46 G. G. d'Ayala, M. Malinconico, P. Laurienzo, A. Tardy, Y. Guillaneuf, M. Lansalot, F. D'Agosto and B. Charleux, J. Polym. Sci., Part A: Polym. Chem., 2014, 52, 104-111.

47 D. Taton, M. Destarac and S. Z. Zard, Handbook of RAFT polymerization, John Wiley \& Sons, 2008.

48 E. Rizzardo, G. Moad and S. Thang, Handbook of RAFT Polymerization, Wiley-VCH, 2008.

49 S. L. Brown, S. Perrier, C. M. Rayner, A. Cooper, S. Graham and S. Rannard, Chem. Commun., 2007, 2145-2147.

50 C. Barner-Kowollik, T. P. Davis and M. H. Stenzel, Chem. Commun., 2004, 1546-1547.

51 A. R. Katritzky, S. Sobiak and C. M. Marson, Magn. Reson. Chem., 1988, 26, 665-670.

52 C. Copeland and R. V. Stick, Aust. J. Chem., 1984, 37, 14831487. 